\title{
A AMBIÇÃO DO OURIÇO: UM ENSAIO SOBRE A VERSÃO FINAL DA FILOSOFIA DO DIREITO DE RONALD DWORKIN
}

THE HEDGEHOG AMBITION: AN ESSAY ABOUT THE FINAL VERSION OF RONALD DWORKIN'S PHILOSOPHY OF LAW

\section{LA AMBICIÓN DEL ERIZO: UN ENSAYO SOBRE LA VERSIÓN FINAL DE LA FILOSOFÍA DEL DERECHO DE RONALD DWORKIN}

Cláudio Ari Mello ${ }^{1}$

Francisco José Borges Motta²

Resumo: Com o presente ensaio, os autores visam a apresentar a estrutura básica do sistema filosófico exposto pelo jusfilósofo norte-americano Ronald Dworkin, ao longo de sua última grande obra, Justice for Hedgehogs, de 2011. O argumento desenvolvido por Dworkin, no citado livro, é composto por três elementos básicos: (i) a tese da independência do valor; (ii) a tese da unidade do valor; (iii) a tese da responsabilidade moral. $O$ texto pretende apresentar estas teses centrais, contextualizando-as com os escritos anteriores de Dworkin, procurando fornecer, ao leitor, uma visão de conjunto do todo de seu trabalho. Com isso, busca-se iluminar aquilo que se pode chamar de versão final da sua célebre teoria do Direito como integridade.

\footnotetext{
${ }^{1}$ Doutor em Teoria do Direito pela UFRGS e Mestre em Direito do Estado pela Pontifícia Universidade Católica do Rio Grande do Sul. Professor da Escola de Direito da Pontifícia Universidade Católica. Promotor de Justiça no Estado do Rio Grande do Sul. E-mail: claudio.ari@hotmail.com.

${ }^{2}$ Doutor e Mestre em Direito Público pela UNISINOS. Professor dos cursos de graduação e mestrado da Faculdade de Direito da Fundação Escola Superior do Ministério Público do Estado do Rio Grande do Sul. Promotor de Justiça no Estado do Rio Grande do Sul. E-mail: bmotta@mp.rs.gov.br.
} 
Palavras-chave: Filosofia do direito. Independência do valor. Unidade do valor. Responsabilidade moral. Direito como integridade.

Abstract: In this paper the authors intend to present the basic structure of the philosophical system presented by the american legal theorist Ronald Dworkin throughout his last major work, Justice for Hedgehogs, from 2011. The argument developed by Dworkin, in the mentioned book, is composed by three basic elements: (i) the independence of value thesis; (ii) the unity of value thesis; (iii) the moral responsibility thesis. The text aims to present these core thesis, contextualizing them with Dworkin's previous writings, aiming to provide to the lector an overview of the whole of his work. This is to clarify what could be called the final version of his notorious Law as Integrity theory.

Keywords: Philosophy of law. Independence of value. Unity of value. Moral responsibility. Law as integrity.

Resumen: En este texto, los autores buscan presentar la estructura básica del sistema filosófico planteado por el filósofo del derecho de EUA, Ronald Dworkin, en su última obra, Justice for Hedgehogs, de 2011. El argumento desarrollado por Dworkin, en el libro, presenta tres elementos básicos: (i) la tesis da la independencia del valor; (ii) la tesis de la unidad del valor; (iii) la tesis de la responsabilidad moral. El texto tiene la intención de presentar esas tesis centrales, contextualizando con los escritos anteriores de Dworkin, con el objetivo de proporcionar al lector una visión de conjunto de su obra. Así, se busca clarear lo que podría llamarse la versión final de su famosa teoría del derecho como integridad.

Palabras clave: Filosofía del derecho. Independencia del valor. Unidad de valor. Responsabilidad moral. El derecho como integridad. 


\section{INTRODUÇÃO}

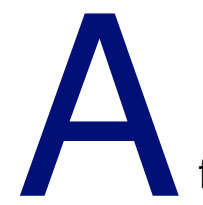

filosofia do direito conheceu um dos mais produtivos períodos de sua história nas últimas décadas. Temas antigos foram retomados e aprofundados, novas questões foram levantadas e exploradas, sempre em um ambiente globalizado, marcado pela fertilização cruzada das diferentes culturas jurídicas e pela reflexão poliglota sobre novas instituições e práticas da experiência jurídica e judicial. Talvez seja possível ousar e reconhecer que a disciplina conheceu a sua era de ouro no período que se inicia logo após a segunda guerra mundial e que ainda está em pleno curso. E essa era de ouro da filosofia do direito produziu alguns autores icônicos, verdadeiramente representativos do pensamento jurídico que se formou nessas décadas douradas. Na galeria desses ícones, sem qualquer dúvida se encontra o norte-americano Ronald Dworkin.

Dworkin tornou-se um dos teóricos do direito mais influentes do pensamento jurídico contemporâneo quando propôs, ainda na década de sessenta do século $\mathrm{XX}$, uma teoria do direito que desafiava a tese da separação conceitual necessária entre direito e moral, que ele considerava, então, o argumento central das concepções positivistas sobre o direito, e defendeu a existência de uma conexão necessária entre o direito e a moral, sem alinhar-se, contudo, às concepções jusnaturalistas tradicionais. Naquele primeiro momento, Dworkin sustentou que a conexão necessária entre as duas esferas ocorria porque todo sistema jurídico seria composto por princípios de moralidade política que a ele pertenceriam independentemente de terem sido incorporados por alguma decisão política de uma autoridade dotada da competência adequada.

Desde a apresentação inicial das suas críticas ao positivismo e de suas teses originais acerca da relação entre direito e moral, o pensamento jurídico de Dworkin foi se tornando notavelmente mais complexo e abrangente. Enquanto a sua distinção entre princípios e regras e a tese de que argumentos essencialmente morais (princípios) teriam conteúdo jurídico normativo ganhavam o mundo e o tornavam célebre, ainda que muito contestado, o autor norte-americano refinava sempre mais a sua compreensão do fenômeno jurídico e, especialmente, a relação entre direito e moralidade. Dworkin continuou um crítico atento e implacável do positivismo jurídico sem jamais insinuar a adesão a qualquer forma de jusnaturalismo, desenvolvendo a sua própria teoria do direito, que chamou de direito como integridade, por ele considerada essencialmente uma teoria interpretativista do direito. 
Compreender as concepções teóricas de Dworkin é, provavelmente, um dos maiores desafios que se pode colocar a um estudioso ou interessado em filosofia do direito, especialmente para aqueles formados na tradição do direito romano-germânico. Não só porque ele é "herdeiro da tradição do pensamento jurídico que se desenvolve nas universidades inglesas e americanas"3 - 0 que, pelas diferenças entre os sistemas da common law e da civil law já poderia fornecer embaraços suficientes -, mas, especialmente, devido à originalidade de seu pensamento com relação a temas reconhecidamente difíceis, polêmicos e distintos. Com efeito, "os seus temas, áreas de interesse e as próprias exigências de sua filosofia o fizeram dirigir sua mirada filosófica para diversos temas que vão desde a filosofia da linguagem, filosofia política, filosofia moral e ética, teoria do direito e direito constitucional"; além disso, seu olhar interdisciplinar dirigiu-se "não apenas aos temas técnicos e herméticos da filosofia profissional, como também, e sobretudo, a temas práticos relevantes presentes na agenda deliberativa da Suprema Corte dos Estados Unidos ou de outra alta corte judiciária ou do legislativo (em especial, mas não apenas, dos EUA e Reino Unido)"4.

$\mathrm{Na}$ apresentação da versão brasileira do livro Ronald Dworkin, de Stephen Guest, Ronaldo Porto Macedo Jr. advertiu que as leituras nacionais do filósofo norte-americano costumam fazer uma interpretação inadequadamente simplificadora de um sistema de ideias complexo. Em alguma medida - segue Macedo Jr. -, isso ocorre porque parcela de seus leitores resume seu estudo de um autor à leitura rápida de alguns poucos artigos, e o fazem de forma descontextualizada e sem visão de conjunto. Esse tipo de leitura, porém, retira o autor de suas premissas e pressupostos metodológicos, prejudicando uma leitura correta de seu pensamento ${ }^{5}$. A bem da verdade, essas apropriações parciais de algumas das ideias de Dworkin pecam pela superficialidade e até mesmo pela incompreensão exatamente porque ignoram que estas ideias estão inseridas em um verdadeiro sistema de pensamento, altamente complexo, porém ricamente interligado.

Esse sistema filosófico foi sendo desenvolvido por Dworkin ao longo de sua prolífica vida literária. Pouco antes de seu falecimento, o autor norte-americano publicou a derradeira obra de exposição do seu pensamento filosófico, intitulada Justice for Hedgehogs ${ }^{6}$, obra que, por suas próprias ambição e importância, logo deflagrou um debate acadêmico de alcance mundial. Nosso

${ }^{3}$ Conforme observa Ronaldo Porto Macedo Jr. na apresentação à versão brasileira de Ronald Dworkin, de Stephen Guest. MACEDO JUNIOR, Ronaldo Porto. Apresentação do livro. In: GUEST, Stephen. Ronald Dworkin. Rio de Janeiro: Elsevier, 2010.

${ }^{4}$ MACEDO JUNIOR, Apresentação.

${ }^{5}$ MACEDO JUNIOR, Apresentação.

${ }^{6}$ DWORKIN, Ronald. Justice for Hedgehogs. Cambridge, Massachusetts, London: The Belknap Press of Harvard University Press, 2011. 
objetivo neste ensaio é, por um lado, expor sinteticamente algumas das principais teses trabalhadas pelo jusfilósofo norte-americano ao longo do livro - concebido, diga-se, como um stand-alone argument, conforme adverte o autor desde o prefácio -, conectando-as, na medida do possível, com suas obras anteriores; e, por outro, agregar observações complementares ao seu pensamento.

Nessa obra, Dworkin explicita com clareza o que, de certa forma, vinha ficando sempre mais evidente em seus textos anteriores, especialmente em Justice in Robes, publicado em 2006. $\mathrm{O}$ autor já não mais considera o direito e moral como sistemas distintos que possuem alguns pontos de interconexão, seja por meio dos princípios de moralidade política ${ }^{7}$, seja por meio da natureza interpretativa da argumentação jurídica ${ }^{8}$. Agora, Dworkin situa o direito como parte do todo representado pelo mundo do valor. Neste sentido muito amplo, o mundo do valor é a instância que define como nós humanos podemos viver uma vida boa, individual e coletivamente. Essa instância, contudo, pode ser compreendida metaforicamente como uma árvore dotada de diversos galhos: a ética, a moral, a moral política e o direito. O direito, por sua vez, é um ramo do galho da moralidade política. Essas subdivisões da estrutura geral do valor coexistem de forma integrada, interagindo e influenciando-se reciprocamente. Não é preciso dizer mais para perceber o quanto o autor aproxima sua concepção jurídica de teorias típicas do pensamento jusnaturalista, sem, contudo, perder a excepcional originalidade da sua concepção não-positivista sobre a natureza do direito.

Não é uma tese simples e Dworkin sempre soube disso. Essa tese naturalmente exigia que ele fundasse a sua teoria do direito em uma filosofia política e as duas em uma filosofia moral. Ou seja, exigia a construção de um verdadeiro sistema filosófico sobre a racionalidade prática, um projeto basicamente incompatível com a tradição da filosofia analítica a qual ele pertence e que só foi esboçado por filósofos do direito declaradamente jusnaturalistas, como John Finnis. Pois bem, Justice for Hedgehogs é o seu esforço final para apresentar e defender esse ambicioso sistema filosófico.

Ao longo do ensaio, com metodologia analítica, vamos nos concentrar em descortinar a estrutura básica do sistema filosófico exposto na obra, que é - eis a nossa hipótese - fundamental para entender o que podemos chamar de versão final da sua teoria do direito como integridade.

7 Como havia feito em Taking Rights Seriously, de 1977. Ver DWORKIN, Ronald. Taking Rights Seriously. Cambridge, USA: Belknapp, 1977 (tradução brasileira: DWORKIN, Ronald. Levando os Direitos a Sério. São Paulo: Martins Fontes, 2002; no ensaio usaremos a versão em português)..

8 Como havia feito em Law's Empire, de 1986. Ver DWORKIN, Ronald. Law's Empire. Cambridge, USA: Belknapp, 1986 (tradução brasileira: DWORKIN, Ronald. O Império do Direito. 2. ed. São Paulo: Martins Fontes, 2003; no ensaio usaremos a versão em português). 
Uma leitura desatenta do livro poderia levar o leitor a pensar que Justice for Hedgehogs na verdade não é um livro de filosofia jurídica, inclusive porque só discute direito nas suas páginas finais, e de forma superficial. Nada mais enganoso. Nessa obra, Dworkin expõe os fundamentos filosóficos sobre os quais se assenta o edifício da teoria do direito como integridade. Isso significa que só podemos compreender plenamente a ambição da sua teoria do direito se assimilarmos a totalidade do seu sistema filosófico. A estrutura desse sistema é composta por três elementos básicos: (i) a tese da independência do valor; (ii) a tese da unidade do valor; (iii) a tese da responsabilidade moral. No ensaio, nos dedicamos a apresentar esses elementos. Se obtivermos algum sucesso nesta empreitada, ao final do trabalho estaremos em condições melhores não só de entendermos a contribuição de Dworkin para o pensamento jurídico contemporâneo, mas, também, de refletirmos criticamente a respeito desta que é, provavelmente, e mais sofisticada e abrangente teoria não-positivista do direito na atualidade ${ }^{9}$.

\section{ENTRE OURIÇOS E RAPOSAS: O MONISMO E O PLURALISMO MORAL}

Desde a sua obra seminal Levando os Direitos a Sério, Dworkin já defendia que uma teoria geral do direito deveria ser ao mesmo tempo normativa e conceitual. Normativa, no sentido de que deveria conter uma teoria da legislação, da decisão judicial e da observância da lei (ainda que assentadas em uma teoria moral e política mais geral); conceitual, no sentido de que faria uso da "filosofia da linguagem e, portanto, também da lógica e da metafísica"10. A ideia central é a de que essas noções são interdependentes e que não podiam, portanto, ser trabalhadas separadamente.

\footnotetext{
${ }^{9}$ A propósito da construção de um teoria do direito com base na teoria dworkiniana, no contexto brasileiro, não podemos deixar de fazer referência, aqui, à extensa obra de Lenio Streck, porém especialmente em Verdade e Consenso. Streck apresenta as bases de uma complexa teoria que se apropria da parte dita normativa da teoria do direito de Dworkin a partir de um olhar filosófico ligado à filosofia hermenêutica de Heidegger e à hermenêutica filosófica de Gadamer, adaptando-a para o contexto do constitucionalismo contemporâneo. Conferir STRECK, Lenio Luiz. Verdade e Consenso: Constituição, Hermenêutica e Teorias Discursivas. 4. ed. São Paulo: Saraiva, 2011. Outra referência indispensável no contexto brasileiro, mas agora com uma apropriação analítica da obra de Dworkin, encontramos na obra de Ronaldo Porto Macedo Junior. Ver MACEDO JUNIOR, Ronaldo Porto. Do Xadrez à Cortesia: Dworkin e a Teoria do Direito Contemporânea. São Paulo: Saraiva, 2013. Ainda, permitimo-nos indicar, dos autores deste ensaio, os seguintes trabalhos: MOTTA, Francisco José Borges. Ronald Dworkin e a Decisão Jurídica. Salvador: Juspodivm, 2017; e MELLO, Cláudio Ari Pinheiro de. Verdade Moral e Método Jurídico na Teoria Constitucional de Ronald Dworkin. In: Alfredo Carlos Storck; Wladimir Barreto Lisboa. (Org.). Normatividade \& argumentação: ensaios de filosofia política e do direito. 1. ed.Porto Alegre: Linus Editores, 2013, p. 285-366.

10 DWORKIN, Ronald. Levando os Direitos a Sério. São Paulo: Martins Fontes, 2002, p. IX-X.
} 
Por assim pensar, Dworkin foi gradativamente posicionando os argumentos centrais de suas teses num quadro cada vez mais abrangente do conhecimento. Passou a discutir com cada vez mais interesse, por exemplo, moralidade, política e filosofia - e nunca de forma compartimentada. Sempre esteve marcada em seus textos a propensão de construir uma teoria que encontrasse certo apoio recíproco entre esses argumentos de natureza aparentemente distinta. Por exemplo, Dworkin identificou objetivos políticos na instituição dos direitos ${ }^{11}$; mapeou princípios morais na base da comunidade política ${ }^{12}$; justificou a igualdade com base em princípios éticos ${ }^{13}$; propôs que se fizesse uma leitura moral da Constituição norte-americana ${ }^{14}$; articulou interpretações filosóficas de conceitos jurídicos. E assim por diante.

Com esse quadro mais geral em vista, Justice for Hedgehogs não chega a ser uma alteração de rota nessa caminhada, digamos assim, interdisciplinar que sempre caracterizou 0 pensamento dworkiniano. A novidade, aqui, é outra: a tentativa, agora abertamente tematizada, de reivindicar um caráter de unidade teórica a proposições oriundas de matrizes distintas. E essa proposta aparece na forma de uma antiga tese filosófica: a tese da unidade do valor (the unity of value thesis ${ }^{15}$ ). O ponto de partida do livro é uma frase do filósofo grego Arquíloco - "The fox knows many things, but the hedgehog knows one big thing" ( $A$ raposa sabe muitas coisas, mas 0 ouriço sabe uma grande coisa) -, tornada conhecida pelo filósofo britânico Isaiah Berlin, que tratou do assunto em 1953, num ensaio sobre Tolstoi ${ }^{16}$. Sinteticamente, o objetivo de Berlin foi o de apresentar o ouriço como uma metáfora do pensador monista, ou seja, como um teórico movido por uma ideia central, que explica a diversidade do mundo por referência a um único sistema. Já a

11 Para Dworkin, um direito político é um objetivo político individuado. DWORKIN, Ronald. Levando os Direitos a Sério, p. 142.

12 Dworkin defende que a comunidade pode ser personificada como um "agente moral", querendo dizer com isto que "a comunidade como um todo tem obrigações de imparcialidade para com seus membros, e que as autoridades se comportam como agentes da comunidade ao exercerem esta responsabilidade". DWORKIN, Ronald. O Império do Direito. 2. ed. São Paulo: Martins Fontes, 2003, p. 211-2.

${ }^{13}$ A teoria política de Dworkin está assentada no fato de que qualquer governo aceitável deve tratar os cidadãos sob seu poder como dignos de igual respeito e consideração. A igual consideração é pré-requisito da legitimidade política, é a virtude soberana da comunidade política. Para defender esse ponto, o autor recorre à etica e desenvolve a concepção de uma forma de igualdade material chamada "igualdade de recursos", baseada em dois princípios fundamentais do individualismo ético: o princípio da igual importância ("é importante, de um ponto de vista objetivo, que a vida humana seja bem-sucedida, em vez de desperdiçada, e isso é igualmente importante, daquele ponto de vista objetivo, para cada vida humana") e o princípio da responsabilidade especial ("embora devamos reconhecer a igual importância objetiva do êxito da vida humana, uma pessoa tem responsabilidade especial e final por esse sucesso - a pessoa dona de tal vida"). DWORKIN, Ronald. A Virtude Soberana: A Teoria e a Prática da lgualdade. São Paulo: Martins Fontes, 2005, p. I-XV.

${ }_{14}$ Trata-se, num resumo bem apertado, de interpretar determinados dispositivos da Constituição norte-americana (sobretudo a Declaração de Direitos) como referências não a concepções específicas, mas a princípios morais abstratos, que devem ser incorporados como limites aos poderes do Estado. DWORKIN, Ronald. O Direito da Liberdade: A Leitura Moral da Constituição Norte-Americana. São Paulo: Martins Fontes, 2006, p. 2.

${ }_{15}$ DWORKIN, Ronald. Justice for Hedgehogs, p. 1.

${ }^{16} \mathrm{O}$ ensaio em questão é referido em nota de revisão da versão brasileira de $A$ Justiça de Toga, publicada pela WMF Martins Fontes. Trata-se de BERLIN, Isaiah. The Hedgehog and the Fox: an essay on Tolstoi's view of history. Elephant Paperbacks, Chicago, 1993. DWORKIN, Ronald. A Justiça de Toga. São Paulo: Martins Fontes, 2010, p. 150. 
raposa, por sua vez, é a metáfora para o pensador pluralista, que entende que a diversidade do mundo, com seus fins múltiplos e incompatíveis, não autoriza um único sistema explicativo.

Neste contexto, Dworkin, intitulando-se um ouriço, anuncia: value is one big thing (o valor é uma grande coisa). Cabe recapitular, porém. Esse debate com Berlin aparece, antes, em $A$ Justiça de Toga, publicado originalmente em 2006. Dada a sua importância para a compreensão dos propósitos de Justice for Hedgehogs, é necessário retomar esse tema com um pouco mais de atenção. Com efeito, ao anunciar que as ideias de Berlin estão ganhando influência, em especial a sua concepção de pluralismo de valores, e com o objetivo de depois respondê-lo, Dworkin transcreve o seguinte recorte do pensamento de seu debatedor:

\begin{abstract}
O que fica claro é que os valores podem entrar em conflito. Eles podem facilmente entrar em conflito no íntimo de um único indivíduo. E disso não se conclui que alguns devam ser verdadeiros, e outros falsos. Tanto a liberdade quanto a igualdade estão entre os principais objetivos perseguidos pelos seres humanos ao longo de muitos séculos. Mas a liberdade total para os lobos significa a morte para os cordeiros. Esses choques de valor constituem a essência do que eles são e do que nós somos. Se nos disserem que essas contradições serão resolvidas em algum mundo perfeito onde todas as coisas boas estarão, em princípio, harmonizadas entre si, devemos responder aos que nos fazem tal afirmação que os significados por eles atribuídos às palavras que, para nós, denotam valores conflitantes, não são iguais aos nossos. Se sofreram alguma transformação, desconhecemos por completo os novos sentidos que assumiram. A noção do todo perfeito, a solução definitiva na qual todas as coisas boas coexistem, parece-me não apenas inatingível - o que constitui um truísmo -, como também conceitualmente incoerente. Entre os grandes bens, existem alguns que não podem viver juntos. Trata-se de uma verdade conceitual. Estamos condenados a escolher, e cada escolha pode significar uma perda irreparável ${ }^{17}$.
\end{abstract}

Dworkin aponta que Berlin retomou esse tema, em ensaio posterior, "de modo mais ameaçador"18. Berlin teria reconhecido que a atração por um todo perfeito seria, apesar de falsa, duradoura e importante. Por outro lado, avalia-a perigosa, recomendando que não se ceda a esse impulso, por ele considerado sintoma de uma "imaturidade moral e política igualmente profunda e perigosa"19.

Fixemo-nos nos argumentos mobilizados por Dworkin para contestar Berlin, que nos permitirão aplainar o terreno para que cheguemos bem a Justice for Hedgehogs. O primeiro passo é apontar que não só esse ideal holístico condenado por Berlin pode ser perigoso: também o pluralismo pode ser mal empregado. Se é verdade que tiranos podem justificar crimes "recorrendo à ideia de que todos os valores morais e políticos se unem em uma visão harmoniosa, de importância tão transcendental que o assassinato se justifica quando está a seu serviço", não é menos verdadeiro dizer que "outros crimes morais têm sido justificados pela atração pela ideia oposta, a de que os valores políticos importantes entram necessariamente em conflito", de modo

17 DWORKIN, Ronald. A Justiça de Toga, p. 149-150. Vale dizer que a passagem transcrita por Dworkin - e aqui reproduzida -, está no livro The Crooked Timber of Humanity: chapters in history of ideas, obra que reúne oito ensaios de Isaiah Berlin.

18 Justamente, o ensaio acima referido, sobre Tolstoi. DWORKIN, Ronald. A Justiça de Toga, p. 150.

${ }^{19}$ DWORKIN, Ronald. A Justiça de Toga, p. 150. 
que "não se pode defender nenhuma escolha entre eles como a única escolha correta e que os sacrifícios em algumas das coisas que nos são caras são, portanto, inevitáveis"20. Ou seja, há perigos em ambos os lados.

O destaque dado a Berlin é de fato decisivo para a fundamentação das concepções filosóficas dworkinianas porque o pensador britânico não é apenas mais um autor cético típico da filosofia moral moderna, que crê serem os valores meras criações sociais contingentes ou projeções subjetivas. Pelo contrário: Berlin - como Dworkin - acreditava que os valores são, de fato, objetivos. O que o distingue do cético comum é a circunstância de, apesar disto, defender que existem conflitos insolúveis entre valores verdadeiros. Berlin identificaria, por exemplo, um conflito efetivo entre os valores da igualdade e da liberdade na decisão a respeito de uma eventual tributação dos ricos para dar mais dinheiro aos pobres. A promoção da igualdade (social), nesse caso, viria com a violação da liberdade de alguns. O contrário (promoção da liberdade mediante a não tributação) também seria verdadeiro: liberdade promovida ao custo da igualdade. De acordo com o raciocínio de Berlin, ambos os valores são autênticos e, em si, inconciliáveis, de modo que a comunidade política cometerá um erro moral qualquer que seja a decisão que resolva tomar. Nesse sentido, sendo as coisas como são, a comunidade não deve definir se vai ser injusta com algum grupo, mas qual grupo tratará injustamente ${ }^{21}$.

A tese de Berlin ataca premissas fundacionais do pensamento filosófico de Dworkin. Como se sabe, desde seus primeiros escritos o autor norte-americano sustentou a tese de que existem respostas certas para todas as questões jurídicas, inclusive para aquelas que exigem a aplicação de princípios morais. Posteriormente, passou a defender a tese mais robusta de que os valores morais são objetivamente verdadeiros e que, por consequência, sempre é possível encontrar uma resposta certa também para os grandes dilemas morais. Evidentemente essas premissas são antitéticas à visão de Berlin, de que muitos conflitos morais e políticos não possuem uma única solução correta e objetiva e de que seu equacionamento implica necessariamente o sacrifício de um ou mais dos valores conflitantes. Sem entender o argumento central de Berlin não fica claro porque a tese central do livro é a unidade do valor. Por isso, mais adiante aprofundaremos este aspecto do debate.

Para defender a tese da unidade do valor, Dworkin afirma explicitamente que acredita na existência de verdades objetivas sobre os valores ${ }^{22}$ e que não se pode defender uma teoria da

\footnotetext{
20 DWORKIN, Ronald. A Justiça de Toga, p. 150-151.

${ }^{21}$ DWORKIN, Ronald. A Justiça de Toga, p. 154-155.

22 DWORKIN, Ronald. Justice for Hedgehogs, p. 07.
} 
justiça sem defender também uma teoria da objetividade moral ${ }^{23}$. Portanto, precisamos antes entender essa teoria antes de prosseguirmos na exploração do projeto do ouriço. $O$ tópico seguinte desse trabalho se dedica a tornar estas premissas mais claras.

\section{A TESE DA INDEPENDÊNCIA DO VALOR}

A sua famosa tese da existência de respostas certas para todas as questões interpretativas do direito gradualmente conduziu Dworkin a sustentar a objetividade dos valores morais. A tese da objetividade tornou-se necessária, em primeiro lugar, porque o autor defendia que, apesar de os princípios de moralidade política terem peso ou importância variáveis conforme o contexto de aplicação, seria possível encontrar, a partir deles, uma resposta certa para cada caso jurídico; a seguir, porque identificar normas jurídicas e decidir processos judiciais exigiria um atividade argumentativa caracterizada pela melhor interpretação do sistema jurídico guiada por princípios morais justificadores. Assim, se os valores morais protegidos por esses princípios não fossem objetivos, a teoria toda desmoronaria e passaria a ser apenas um mecanismo de imposição arbitrária de preferências ou inclinações subjetivas dos intérpretes jurídicos.

Como já vinha fazendo com clareza ao menos desde o ensaio Obcjectivity and Truth: You'd Better Believe It, de 1996, em Justice for Hedgehogs, o autor fundamenta a tese da objetividade dos valores morais defendendo a independência do domínio moral em relação ao domínio do mundo natural, ou, para ser mais preciso, a independência da verdade dos juízos morais em relação à verdade das proposições sobre fatos naturais. Essa concepção nãonaturalista sobre a moralidade é defendida com base naquilo que Dworkin chamou de princípio de Hume. ${ }^{24}$ No Tratado sobre a Natureza Humana, David Hume afirmou, em síntese, que não se podem deduzir proposições sobre o dever ser de proposições sobre o ser. Hume criticou o que ele chamou de prática comum de extrair, do modo ordinário de raciocinar, da observação da ação humana ou do estabelecimento da existência de um deus, proposições sobre como as coisas devem ser ou não devem ser ${ }^{25}$.

Dworkin deduz desse argumento a completa separação ontológica e epistemológica entre o mundo natural e a moral. O mundo natural é composto por fatos e objetos físicos e as verdades sobre o mundo natural são demonstradas por verificação e comprovação empíricas. A moral é o

${ }^{23}$ DWORKIN, Ronald. Justice for Hedgehogs, p. 08.

${ }^{24}$ Para uma abordagem sobre teorias morais naturalistas e não-naturalistas, ver MILLER, Alexander. An Introduction to Contemporary Metaethics. Cambridge, UK: Polity Press, 2003, especialmente capítulos 2 e 3.

${ }^{25}$ HUME, David. Treatise of Human Nature. Oxford: Oxford University Press, 2000, p. 301-302. 
domínio dos argumentos racionais e as verdades morais são demonstradas por meio de uma argumentação responsável acerca da ação humana, que seja capaz de produzir uma rede integrada de razões que sustentem e reforcem mutuamente cada uma delas até a obtenção de uma resposta coerente. Procurar argumentos metafísicos para demonstrar ou refutar juízos morais é violar o princípio de Hume, porque de proposições descritivas ou juízos factuais não podemos deduzir juízos de valor. Juízos morais só podem ser demonstrados verdadeiros por meio de argumentos morais.

A defesa da objetividade dos valores morais exigiu de Dworkin atacar as teses céticas acerca da moralidade. Ao sustentar que existem valores morais verdadeiros, ou que o conceito de verdade pode ser aplicado para juízos morais, Dworkin teve naturalmente de enfrentar as teses que negam essa possibilidade, e essa é a razão pela qual atacar o ceticismo moral tornou-se um estágio indispensável para a estratégia teórica do autor. Todavia, antes ainda de rejeitar o ceticismo, o autor propõe uma tese ousada e polêmica, que servirá de premissa para seu ataque às teses céticas.

A filosofia moral contemporânea divide-se essencialmente em dois grandes ramos: a ética e a metaética. A ética se preocupa com os juízos morais substantivos sobre a vida humana ou sobre ações humanas. Juízos éticos se posicionam sobre a justiça ou injustiça, a bondade ou a maldade, a correção ou a incorreção de ações humanas. Dizer que a tortura é má, que a pobreza extrema é injusta e que o aborto é errado são juízos éticos substantivos. A metaética se ocupa da natureza ou do status teórico dos juízos morais. Ela investiga se proposições morais podem ou não ser fundamentadas com base em fatos da natureza humana, como emoções, intuições, projeções, características genéticas, predisposições naturais ou interesses estratégicos, em fatos sociais, como convenções e costumes de grupos humanos, ou fatos sobrenaturais, como a existência de seres divinos que governam ou influenciam a ação humana. Juízos éticos são proposições morais de primeira ordem e proposições metaéticas são proposições morais de segunda ordem. Esse é o senso comum das investigações contemporâneas sobre a filosofia moral. Essa divisão gerou uma série de subdivisões no campo da metaética. Normalmente elas são agrupadas em dois grandes grupos: as teorias cognitivistas e as não-cognitivistas. Entre essas, existem teorias realistas, subjetivistas, emotivistas, expressivistas, relativistas, projetivistas, construtivistas ${ }^{26}$.

${ }^{26}$ Ver, sobre o tema, a síntese dessas correntes produzida por FERREIRA NETO, Arthur Maria. Metaética e a Fundamentação do Direito. Porto Alegre: Elegantia Juris, 2015. A literatura internacional sobre o tema é inesgotável. Podem ser citadas como exemplos de excelentes obras introdutórias sobre a metaética: MILLER, Alexander. An Introduction to Contemporary Metaethics. Cambridge, UK: Polity Press, 2003; SCHROEDER, Mark. Noncognitivsm in Ethics. London: Routledge, 2010; TIMMONS, Mark. Moral Theory: An Introduction. Maryland: 
Dworkin rejeita essa separação. Para ele, não existem juízos morais de segunda ordem e toda a metaética é fundada em um erro. Proposições sobre a moralidade, inclusive aquelas que se referem à natureza teórica de juízos morais substantivos, são sempre juízos de primeira ordem, ou seja, juízos que se posicionam positiva ou negativamente sobre questões morais. Isso acontece porque não existem fatos morais ou propriedades morais sobre fatos naturais. Como ele afirmou ironicamente desde Objetivity and Truth: You'd Better Believe It, não existem morons, partículas morais existente no mundo natural que poderiam comprovar empiricamente a veracidade de proposições morais. Juízos morais positivos ou negativos, que afirmam ou negam verdades sobre questões morais são sempre e apenas juízos substantivos e argumentativos a respeito de questões de moralidade. Atribuir a origem dos nossos juízos morais a emoções, expressões, projeções ou inclinações é apenas uma forma de enfatizar, repetir ou reafirmar as nossas convicções morais substantivas, que não necessitam desse reforço para serem verdadeiras. Por isso, a metaética é um empreendimento filosófico equivocado e deve ser abandonada ${ }^{27}$.

A refutação da metaética tem como objetivo central preparar o terreno para a sua cruzada contra as teses céticas sobre a moralidade, embora atinja também as teorias que defendem o realismo moral. $\mathrm{O}$ autor distingue duas formas básicas de doutrinas morais céticas: o ceticismo externo e o ceticismo interno. O ceticismo externo rejeita a existência de verdades morais e sustenta uma concepção filosófica sobre a moralidade que pretende ser ela mesma externa à moralidade. O ceticismo externo pode assumir duas teses distintas. O ceticismo do erro afirma que todos os juízos morais positivos são falsos. Conceitos morais como bondade, justiça, obrigação não encontram no mundo qualquer propriedade que possa confirmá-los como verdadeiros. A própria existência de diferentes concepções morais rivais, em lugares e épocas diferentes, demonstra que os valores morais são apenas posições subjetivas e relativas que não podem ser justificadas objetivamente. O ceticismo do status afirma que as proposições morais substantivas são derivadas de emoções, projeções ou preferências subjetivas, muitas geneticamente explicáveis, de cálculos estratégicos de interesse ou de tradições culturais particulares. No entanto, essas posições subjetivas não podem ser alçadas ao nível da objetividade, ou seja, elas efetivamente existem, mas não podem ter o status de proposições objetivas ou universais. Os fatos naturais aos quais elas correspondem podem ser observados e

Rowman and Littlefield Publishers, 2013; FISCHER, Andrew. Metaethics: An Introduction. London: Routledge, 2014; ROOJEN, Mark van. Metaethics: A Contemporary Introduction. London: Routledge, 2015; SCHAFER LANDAU, Russ (editor). Oxford Studies in Metaethics. Oxford: OUP, 2016.

27 Uma crítica importante, ainda que bastante sucinta, ao ataque dworkiniano à metaética foi exposta por Simon Blackburn em um conhecido comentário sobre o artigo Objectivity and Truth: You'd Better Believed It, que pode ser acessado em www.brown.edu/Departments/Philosophy/bears/9611blac (acesso em 04.03.2017). Blackburn é conhecido por ter proposto uma concepção metaética que ele denominou de "quase-realismo"; no texto referido, este autor sustenta que algumas das teses centrais de Dworkin reproduzem as suas próprias ideias "quase-realistas". Ver BLACKBURN, Simon. Essays in Quase-Realism. Oxford: Oxford University Press, 1993. 
representados, mas não podem ser considerados como universalmente válidos ou como objetivamente verdadeiros.

O ceticismo externo sustenta que podemos examinar o domínio moral a partir de uma perspectiva externa a ele, ou seja, trata-se de uma perspectiva que se pretende claramente metaética. Dworkin chama essa atitude de arquimedianismo ${ }^{28}$. 0 cético externo parte do princípio de que é possível examinar o mundo moral como um filósofo ou um cientista neutro e moralmente desengajado, que tem como objetivo testar o status de verdade de crenças ou proposições morais, a fim de verificar se a moral é capaz de produzir verdades objetivas como a ciência pode produzir conhecimento objetivamente verdadeiro sobre fatos naturais. A investigação teórica sobre a natureza ou metafísica das proposições morais não envolve a adoção de juízos substantivos sobre questões morais. As teses céticas exteriores concluem que a natureza das proposições morais é tal que jamais podemos afirmar que valores ou juízos morais são verdadeiros ou objetivos. Ou bem é um erro admitir que existem juízos morais de qualquer natureza (ceticismo do erro), ou bem é possível formular juízos morais, porém eles são apenas produto de condicionamentos biológicos, emoções, projeções, preferências subjetivas, interesses pessoais ou tradições culturais, incapazes de serem considerados objetivos ou verdadeiros (ceticismo do status).

Dworkin afirma que as duas espécies de ceticismo metaético são insustentáveis. O cético do erro somente pode afirmar que juízos morais substantivos positivos são necessariamente falsos. Juízos morais positivos são aqueles que oferecem orientação para a ação humana ou para o julgamento de um caráter, como juízos que dizem se uma ação é moralmente obrigatória ou proibida, se alguém é virtuoso ou é uma pessoa má ${ }^{29}$. Os céticos do erro afirmam que esses juízos são falsos porque não correspondem a estados de coisas reais; assim, jamais é possível sustentar racionalmente que uma ação é objetivamente justa ou injusta, ou que uma pessoa é objetivamente boa ou má30 . No entanto, diz o autor, a proposição segundo a qual uma ação não é justa nem injusta, uma pessoa não é boa nem má, continua a ser um juízo moral, ou seja, continua sendo uma proposição substantiva sobre a ação humana ou sobre o caráter de uma pessoa,

${ }^{28}$ É interessante registrar que a crítica ao arquimedianismo na filosofia moral já apareceu no ensaio O Ouriço e a Raposa de Isaiah Berlin. Ver BERLIN, Isaiah. O Ouriço e a Raposa. In: Ensaios sobre a Humanidade. São Paulo: Companhia das Letras, 2002, p. 502-503.

${ }^{29}$ DWORKIN, Ronald. Justice for Hedgehogs, p. 47.

30 Richard Joyce, um dos mais influentes filósofos céticos da atualidade, compara o ceticismo do erro com a concepção que um ateu tem a respeito da religião. Uma crença religiosa, para um ateu, é uma visão subjetiva que não pode ser confirmada por nenhum objeto ou propriedade da realidade. Como essa confirmação é impossível, qualquer crença em um deus é um erro. O mesmo raciocínio vale para a moralidade. Logo abordaremos essa questão. Ver JOYCE, Richard. Essays in Moral Skepticism. Oxford: Oxford University Press, 2016, p. 3-4. 
independentemente de haver ou não um fato natural a que corresponda ou uma diversidade de culturas morais. Portanto, o ceticismo do erro fracassa ${ }^{31}$.

O ceticismo do status também não é defensável porque, qualquer que seja a natureza das proposições sobre a moral, sejam elas o produto de emoções humanas, de condicionamentos genéticos ou a expressão de uma estratégia de vida, elas sempre se resolvem em uma tomada de posição sobre questões substantivas de natureza moral, e quando fazem isso, os céticos do status não podem escapar de submeter-se à forma típica da afirmação de juízos morais, que é prática argumentativa baseada em razões morais. Ao defenderem juízos morais sobre a conduta e o caráter humanos, os céticos do status não podem simplesmente dizer que a proposição segundo a qual a tortura de crianças por diversão é errada ou a pena de morte de inocentes é injusta não passa de um produto de uma emoção pessoal ou a expressão de uma forma de vida. Se fizerem isso, visando a negar o status de verdade objetiva da proposição, estarão também fazendo um discurso racionalmente incoerente.

O ceticismo interior, por sua vez, não adota uma posição externa em relação à moralidade. $O$ cético interior admite a existência da moralidade e a possibilidade de formular proposições morais verdadeiras. Contudo, ele é cético em relação a algumas questões, mais ou menos abrangentes, acerca da moralidade. $O$ ceticismo interior pode ser limitado a uma questão específica da moralidade, como a possibilidade de encontrarmos respostas certas sobre o valor da vida ou sobre questões envolvendo a sexualidade humana. Mas pode adotar também uma concepção bem mais abrangente, afirmando, por exemplo, que todos os juízos morais positivos são falsos, e apenas juízos morais negativos podem ser verdadeiros. O cético interno pode admitir, por exemplo, que se houvesse um ser divino todo-poderoso, todas as suas prescrições morais seriam verdadeiras, mas como não existe um ser dessa natureza, todos os juízos morais positivos são falsos.

Contudo, diz o autor, a proposição segundo a qual determinadas questões morais não possuem uma resposta objetiva e verdadeira também depende de argumentos da mesma

31 DWORKIN, Ronald. Justice for Hedgehogs, p. 08. Entretanto como em muitas outras de suas batalhas contra a metaética, é duvidoso que Dworkin tenha respondido plenamente aos argumentos do principal cético do erro, John Mackie. Segundo Mackie, é um erro afirmar que existem valores morais objetivos porque, "se houvesse valores objetivos, então eles seriam entidades ou relações de um tipo muito estranho, completamente diferente de qualquer outra coisa no universo" (MACKIE, John. Ethics: Inventing Right and Wrong. New York: Penguin, 1977, p. 38). Trata-se do conhecido argumento denominado de queerness (de difícil tradução; provavelmente estranhidade pudesse servir para nos aproximarmos do significado do termo). Mackie sustentou que, para considerarmos juízos morais como objetivamente verdadeiros, seria necessário um tipo de faculdade, intuição ou percepção muito diferente de tudo o que sabemos sobre as faculdades dos seres humanos. Este é um argumento tipicamente metaético. Mackie pode estar errado; porém, se estiver certo, então não poderíamos de fato considerar como verdadeira qualquer proposição moral, salvo se usarmos o termo verdade como algo completamente diverso dos significados atribuídos a ele. Contudo, nossa proposta no ensaio restringe-se a expor as posições de Dworkin, por isso não examinaremos a correção teórica da crítica do autor a esta forma de ceticismo. 
natureza daqueles exigidos para a demonstração de juízos morais substantivos. A afirmação de que a questão do casamento homossexual é moralmente indeterminada somente se sustenta com argumentos racionais tão exigentes quanto aqueles utilizados para defender ou atacar a prática.

Quando este cético afirma que não existe nenhuma resposta certa acerca do valor da vida na discussão sobre o aborto e a eutanásia, ou que o valor da vida depende da interpretação que cada comunidade dá a ela, ele está propondo que essa é a resposta certa, e para fazer prevalecer essa proposição está obrigado a comprová-la por meio de argumentos, exatamente como aqueles que afirmam ou negam a prevalência da vida sobre a autonomia reprodutiva da mulher ou sobre a autodeterminação existencial do doente terminal.

Para o autor, o ceticismo que realmente representa um desafio para a sua teoria da objetividade moral é o ceticismo interno. Ao longo da sua trajetória filosófica, Dworkin foi refinando a sua tese da única resposta certa e explicitando que algumas questões morais e jurídicas podem não ter, de fato, uma única resposta certa, ou seja, podem ser realmente indeterminadas. Provavelmente foi a sensibilidade ao ceticismo interno que o levou a explorar essa possibilidade, potencialmente contraditória com a sua tese original. Entretanto, ele nem por isso deixou de refutar o ceticismo interno. A indeterminação, diz o autor, não é, a rigor, uma posição cética, mas uma posição moral como outra qualquer, que impõe ao seu defensor o mesmo ônus argumentativo daquele que sustenta outra posição moral substantiva ${ }^{32}$.

O ceticismo externo, por sua vez, é completamente rejeitado por Dworkin. A tese da independência do valor e a exposição do princípio de Hume têm exatamente esse objetivo, o de atacar os próprios pressupostos filosóficos da metaética, que teria ficado refém da concepção de verdade típica das ciências naturais, procurando uma fundação teórica que essas ciências não podem dar para a moral. A moralidade é o domínio da argumentação racional e responsável, e não o reino da prova empiricamente observável. Em um parágrafo tipicamente ácido de Justice for Hedgehogs ele define a sua visão sobre o ceticismo externo e o próprio projeto da metaética:

O ceticismo externo devia desaparecer da paisagem filosófica. E não deveríamos lamentar o seu desaparecimento. Temos demasiado com que nos preocupar sem ele. Queremos viver bem e comportar-nos de forma decente; queremos que nossas comunidades sejam equitativas e boas e nossas leis sejam inteligentes e justas. Trata-se de objetivos difíceis, em parte porque as questões em jogo são complexas e obscuras e, em parte, porque o egoísmo se entrepõe muito frequentemente no caminho. Quando nos dizem que todas as convicções que nos esforçamos por alcançar não podem, em caso algum, ser verdadeiras ou falsas, ou

\footnotetext{
32 Aqui, cabe trazer à luz a distinção traçada, por Dworkin, entre indeterminação e incerteza. Uma coisa é, depois de um estudo cuidadoso, não encontrar um argumento persuasivo em favor de qualquer das soluções juridicamente possíveis. Isso é apenas incerteza, que, de fato, é a resposta por omissão (by default) - você não está certo de qual resposta é correta. Outra coisa é a indeterminação: a afirmação positiva, conclusiva, de que nenhuma das alternativas é correta. Dizer que você não tem certeza é diferente de afirmar que não há resposta certa. Se a primeira é a resposta por default, a segunda depende de uma defesa (um case) em seu favor, tanto quanto as demais propostas de interpretação. DWORKIN, Ronald. Justice for Hedgehogs, p. 90-1.
} 
objetivas, ou parte daquilo que conhecemos, ou que são apenas jogadas num jogo de linguagem, ou apenas vapor das turbinas das nossas emoções, ou apenas projetos experimentais que devemos fazer para saber se funcionam, ou apenas convites a pensamentos que podemos achar divertidos ou menos aborrecidos do que as maneiras habituais de pensar, devemos responder que todas as nossas observações são distrações inconsequentes dos verdadeiros desafios que temos pela frente. Não quero dizer que devemos ignorar o ceticismo moral. Pelo contrário. O ceticismo genuíno - o ceticismo interno - é muito mais preocupante do que essas confusões filosóficas ${ }^{33}$.

Como em seus escritos anteriores sobre o tema, em Justice for Hedgehogs o autor prioriza extensamente a refutação de todas as formas de ceticismo. Entretanto, a tese da independência da moral rejeita também qualquer forma de realismo moral, e, portanto, as teorias jusnaturalistas baseadas nesta concepção metaética. Conforme vimos antes, a tese da independência da moral tem como premissa a ausência de relação de implicação entre fatos naturais e juízos morais. Proposições sobre fatos naturais podem ser verdadeiras por correspondência. Proposições sobre questões morais não podem ser verdadeiras por correspondência simplesmente porque não existem fatos morais em relação aos quais elas possam corresponder. Uma verdade moral é o produto de uma argumentação rigorosa que procura construir a resposta mais coerente possível ${ }^{34}$. Não há nada "no mundo lá fora" (out there) além da argumentação racional coerentista com que se possa contar para atingir uma verdade moral.

Assim é como Dworkin estrutura e defende a sua teoria da objetividade da moral. A tese da independência da moral é a sua estratégia para dar suporte filosófico à teoria. A defesa da tese o levou a desqualificar totalmente a metaética, uma das mais vistosas conquistas da filosofia analítica para o ramo da filosofia moral do século passado. Trata-se, portanto, de um corajoso desafio filosófico. Muitas críticas bem fundamentadas foram feitas à tese, inclusive especificamente aos argumentos expostos no livro que estamos examinando ${ }^{35}$. No entanto, a análise da correção teórica dos complexos fundamentos das teses do autor não pode ser feita neste ensaio. Nosso objetivo até aqui foi tão somente o de expor sinteticamente a estratégia teórica do autor na defesa da sua teoria moral.

\footnotetext{
${ }^{33}$ DWORKIN, Ronald. Justice for Hedgehogs, p. 68.

34 "Os juízos morais são verdadeiros, quando são verdadeiros, não em virtude de alguma correspondência, mas sim face à defesa substantiva que deles pode ser feita. O domínio da moral é o domínio do argumento, não do fato bruto e material" (Justice for Hedgehogs, p. 23).

35 Ver SHAFFER-LANDAU, Russ. Truth and Metaethics: The Possibility of Metaethics, Boston University Law Review, vol. 90, n. 2 (abril 2010), p. 479-496, SMITH, Michael. Dworkin on External Skepcism, Boston University Law Review, vol. 90, n. 2 (abril 2010), p. 509-520, FERREIRA NETO, Arthur Maria. Metaética e a Fundamentação do Direito, p. 249-300.
} 


\section{A TESE DA UNIDADE DO VALOR}

No ensaio Dois Conceitos sobre a Liberdade, Isaiah Berlin enfrenta as concepções morais que ele chama de monistas, segundo as quais sempre há uma única solução verdadeira para cada problema moral e a verdade moral pode ser descoberta por qualquer pensador racional e demonstrada de tal forma que qualquer outro ser racional não poderia deixar de aceitar ${ }^{36}$. Os filósofos monistas acreditariam em uma "harmonia final em que todos os enigmas são resolvidos, todas as contradições conciliadas"37. É exatamente essa visão filosófica harmonizadora dos grandes conflitos morais e políticos da humanidade que Berlin procura desacreditar com a sua concepção pluralista sobre a moralidade política.

Para Berlin, no mundo da experiência comum somos inevitavelmente confrontados com a pluralidade de valores morais e políticos, como liberdade, igualdade, democracia e justiça. Esses valores entram em conflito e competem entre si e muitas vezes não é possível superar esse conflito por qualquer mecanismo racional. Nesses casos, estamos condenados a escolher um valor e sacrificar um outro: "o mundo em que nos encontramos na experiência comum é um mundo em que somos confrontados com escolhas entre fins igualmente supremos e reivindicações igualmente absolutas, e a realização de algumas dessas escolhas e reivindicações deve envolver necessariamente o sacrifício de outras" 38 .

Essa é uma situação trágica à qual a humanidade não pode escapar, porque "a crença de que em princípio há uma fórmula única, pela qual todos os diversos fins humanos possam ser harmoniosamente realizados, é demonstravelmente falsa" ${ }^{39}$. A necessidade de escolher entre valores e fins que competem e conflitam entre si na experiência prática do ser humano é "uma característica inevitável da condição humana"40. Portanto, o monismo não passa de uma pretensão filosófica ingênua e irrealizável. Nada pode nos salvar do pluralismo dos valores e da tragédia da escolha e do sacrifício. Mais do que isso: somente o pluralismo pode realmente promover o valor da liberdade que se exerce justamente no ato de escolher livremente entre valores e fins colidentes:

O pluralismo, com a dose de liberdade "negativa" que acarreta, parece-me um ideal mais
verdadeiro e mais humano do que as metas daqueles que buscam nas grandes estruturas
disciplinadas e autoritárias o ideal do autodomínio "positivo" por parte de classes, povos ou
de toda a humanidade. É mais verdadeiro, pois pelo menos reconhece o fato de que as

${ }^{36}$ BERLIN Isaiah. Two Concepts of Liberty. In: BERLIN, Isaiah. Liberty. Oxford: Oxford University Press, 2009, p. 191192.

37 BERLIN, Isaiah. Two Concepts of Liberty, p. 213

${ }^{38}$ BERLIN, Isaiah. Two Concepts of Liberty, p. 213-214.

39 BERLIN, Isaiah. Two Concepts of Liberty, p. 214.

40 BERLIN, Isaiah. Two Concepts of Liberty, p. 214. 
metas humanas são muitas, nem todas comensuráveis, e em perpétua rivalidade umas com as outras ${ }^{41}$.

Essa é a concepção filosófica que Dworkin ataca com a tese da unidade do valor. Ou seja, ele procura resgatar precisamente a visão monista da vida moral que Berlin se esforça para desautorizar no seu célebre ensaio sobre a liberdade. Dworkin sugere que nos engajemos na tarefa de formular concepções que unifiquem, de alguma forma, esses valores políticos importantes, preservando-os naquilo que há de bom em cada um deles. A intenção é que a liberdade, bem compreendida, não conflite com a igualdade. Que a melhor interpretação do que seja a democracia, por exemplo, seja harmônica e coerente com a melhor maneira de interpretar a justiça.

É dessa ambiciosa empreitada que trata a tese da unidade do valor, na visão apresentada por Dworkin. E o ponto de partida não poderia ser mais generalizante: o autor não se limita a tratar de valores e conceitos políticos e jurídicos. Avançando para um campo bem mais familiar à filosofia moral do que ao direito, o autor norte-americano começa sua obra afirmando que as verdades a respeito das noções de bem viver, de ser bom, ou do que é maravilhoso, são não só coerentes, mas também se apoiam reciprocamente. Isto é, o que pensamos a respeito de qualquer uma dessas coisas pode aparecer como um argumento decisivo em qualquer discussão sobre as demais. Há harmonia, e não conflito. Seguindo essa linha, Justice for Hedgehogs visa a ilustrar a unidade entre os valores morais e éticos: descreve uma teoria sobre o que é viver bem (Ética) e sobre aquilo que, se quisermos viver bem, nós devemos fazer e deixar de fazer pelos outros (Moral) ${ }^{42}$.

A ideia central, como se vê, é a de que os valores morais e éticos dependem uns dos outros e a verdade sobre eles resulta de interpretá-los e apresenta-los à sua melhor luz, ou seja, como parte de uma concepção que permita as melhores condições possíveis para a promoção de uma vida boa. Ao contrário do que propõem o pluralismo e qualquer outra teoria que sustente a insolubilidade de todos ou de alguns conflitos morais e políticos, para Dworkin a própria compreensão do significado de cada valor depende de uma compreensão unificada dos demais valores que incidam na mesma questão prática da vida humana. O significado de um valor só

\footnotetext{
41 BERLIN, Isaiah. Two Concepts of Liberty, p. 216-217.

42 DWORKIN, Ronald. Justice for Hedgehogs, p. 1. Dworkin elabora uma metáfora para ilustrar essa distinção traçada entre moral e ética. O autor imagina pessoas nadando em pistas separadas de uma piscina, que podem trocar de pista para auxiliar os outros nadadores, porém não para machucá-los. A moral, neste sentido, definiria as pistas que separam os nadadores; e estipularia quando alguém deve trocar de pista para ajudar os outros nadadores e em que condições seria proibida a troca de pistas. A ética estaria ocupada em definir o que é nadar bem em sua própria pista (DWORKIN, Ronald. Justice for Hedgehogs, p. 371). Como se sabe, a distinção conceitual entre moral e ética é uma das questões mais tormentosas da história da filosofia prática. Dworkin as concebe como instâncias diferentes do mundo do valor e, a nosso juízo, oferece uma distinção conceitual bem clara entre elas.
} 
pode ser compreendido e construído na sua relação com os demais valores a ele associados. Trata-se de uma concepção claramente holística da moralidade. O holismo moral, diz o autor,

(é) a fé do ouriço em que todos os valores formam uma rede interligada, em que todas as nossas convicções sobre o que é bom, correto ou belo desempenham um papel de suporte a todas as nossas outras convicções em todos os domínios do valor. Só podemos procurar a verdade sobre a moralidade, se aprovarmos a coerência aprovada pela convicção ${ }^{43}$.

Antes de prosseguirmos, é necessário fazer um esclarecimento metodológico indispensável para entender a teoria da unidade do valor. Para o autor, os valores morais são expressados a partir de conceitos tipicamente interpretativos. Um conceito interpretativo é formado a partir da investigação, da análise crítica e da interpretação das finalidades que explicam e justificam o valor. Os teóricos que pretendem compreender o conceito não necessitam estar de acordo quanto aos critérios que usam para identificá-lo. Eles podem usar o conceito que aplicam à prática mesmo quando divergem acerca de quais são os critérios que devem ser usados para explicá-lo. Por isso, a mera descrição da prática é sempre insuficiente e ineficiente. É sempre necessária uma interpretação dela. Uma vez que reconhecemos a finalidade da prática social envolvida no valor, para elaborar um conceito que defina esse valor devemos apresentá-lo em sua melhor perspectiva, isto é, de um modo que essa definição permita que a prática realize da melhor maneira possível as suas finalidades fundamentais. Essa atividade é uma interpretação do valor em questão. Portanto, o procedimento de construção do significado de um conceito interpretativo é normativo, e não meramente descritivo. A seguinte passagem evidencia o que o autor tem em mente com a ideia de conceito interpretativo:

Uma interpretação particular é bem-sucedida - atinge a verdade sobre o significado de um objeto - quando realiza melhor, em relação a esse objeto, os propósitos adequadamente atribuídos à prática interpretativa apropriadamente identificada como pertinente. A interpretação, portanto, pode envolver, analiticamente, três estágios. Em primeiro lugar, interpretamos práticas sociais quando individuamos essas práticas, quando nos engajamos em uma interpretação legal e não uma interpretação literária. Em segundo, quando atribuímos algum conjunto de propósitos ao gênero ou subgênero que identificamos como pertinente, e, em terceiro, quando tentamos identificar a melhor realização desse conjunto de propósitos em uma ocasião particular ${ }^{44}$.

Para Dworkin, a interpretação é sempre um empreendimento holístico. A compreensão e a justificação de um valor exige "uma integração de valores morais de fundo e de ideias interpretativas concretas" ${ }^{45}$. Diferentemente de um conceito científico, que pode ser afirmado verdadeiro pela sua correspondência com o mundo natural, as proposições interpretativas "só podem ser verdadeiras em virtude uma justificação interpretativa retirada de um complexo de valores, nenhum dos quais também simplesmente verdadeiro"46. Essa é a razão pela qual ele

\footnotetext{
${ }^{43}$ DWORKIN, Ronald. Justice for Hedgehogs, p. 120.

${ }^{44}$ DWORKIN, Ronald. Justice for Hedgehogs, p. 131.

${ }^{45}$ DWORKIN, Ronald. Justice for Hedgehogs, p. 134-135

${ }^{46}$ DWORKIN, Ronald. Justice for Hedgehogs, p. 153-154.
} 
propõe que o método para definir conceitos morais deve corresponder a uma "epistemologia integrada", isto é, a um modo de compreender cada valor que só pode atribuir o verdadeiro sentido dele quando buscamos torná-lo compatível e coerente com os demais valores pertinentes, que, por sua vez, só podem ser compreendidos e justificados de forma igualmente integrada ${ }^{47}$.

O holismo moral e a epistemologia integrada propostos por Dworkin podem ser melhor compreendidos quando examinamos os conceitos de igualdade e de liberdade expostos na obra e as relações entre esses valores que nela são exploradas. Um dos conflitos morais frequentemente insolúveis na visão de Isaiah Berlin ocorria entre esses dois valores:

Tudo o que é, é: liberdade é liberdade, não é igualdade, equidade, justiça ou cultura, felicidade humana ou uma consciência tranquila. Se minha liberdade ou de minha classe ou nação depende da desgraça de outros seres humanos, o sistema que promove tal coisa é injusto e imoral. Mas se restrinjo ou perco minha liberdade para diminuir a vergonha dessa desigualdade, e com isso não aumento materialmente a liberdade individual de outros, ocorre uma perda absoluta de liberdade. Isso pode ser compensado por um ganho em justiça, felicidade ou paz, mas a perda permanece, e é uma confusão de valores dizer que, embora minha liberdade "liberal", individual seja jogada fora, algum outro tipo de liberdade "social" ou "econômica" - é aumentada. Ainda assim continua verdadeiro que a liberdade de alguns deve às vezes ser restringida para assegurar a liberdade de outros ${ }^{48}$.

É exatamente contra essa alegada inevitabilidade do sacrifício de valores concorrentes que Dworkin mobiliza sua concepção holística. Ele procura definir interpretativamente conceitos sobre os valores que permitam a coexistência e a complementariedade entre eles, não o sacrifício. Como são conceitos interpretativos e interativos, eu só posso definir adequadamente o que é liberdade na medida em que eu assegure os seus fins promovendo simultaneamente os fins fundamentais da igualdade, e vice-versa. A forma como ele integra igualdade e liberdade para a construção da justiça ilustra o método da epistemologia integrada e pode nos ajudar a entender melhor sua proposta.

$\mathrm{Na}$ visão dworkiniana, nenhum governo é legítimo sem que endosse dois princípios. Primeiro, deve demonstrar igual interesse pelas pessoas que estão sob o seu domínio49; segundo, deve respeitar a responsabilidade e o direito dessas pessoas de eleger o que é valioso para si

${ }^{47}$ Este é um ponto em que a teoria "quase-realista" de Simon Blackburn pode reivindicar precedência, ao menos parcial, em relação à teoria moral de Dworkin, ao menos na forma apresentada a partir de Objectivity and Truth. Blackburn é um projetivista moral, que, portanto, tal como Dworkin, nega a existência de fatos morais ou de propriedades morais intrínsecas ao mundo natural. Juízos morais são projeções dos sentimentos humanos sobre os fatos naturais. Entretanto, ele sustenta que nós podemos "ganhar o direito (earn the right) à noção de verdade moral" na medida em que obtenhamos coerência e consistência entre as nossas sensibilidades morais e nossos compromissos morais verdadeiros expressem atitudes que façam parte do melhor conjunto possível de atitudes (ver BLACKBURN, Simon. Spreading the Word. Oxford: Oxford University Press, 1984). Perceba-se que a expressão "ganhar o direito" à verdade moral é idêntica à noção de "ganhar o direito" à única interpretação correta exposta por Dworkin.

${ }^{48}$ BERLIN, Isaiah. Two Concepts of Liberty, p. 172.

49 Dworkin presume que "todos aceitamos os seguintes postulados da moral política. O governo deve tratar aqueles a quem governa com consideração, isto é, como seres humanos capazes de sofrimento e de frustração e com respeito, isto é, como seres humanos capazes de formar concepções inteligentes sobre o modo como suas vidas são vividas, e de agir de acordo com elas." DWORKIN, Ronald. Levando os Direitos a Sério, p. 419. 
mesmas. Esses princípios devem guiar uma teoria aceitável de justiça distributiva. Qualquer distribuição deve ser justificada pela demonstração de atendimento aos princípios de igual consideração e de respeito pela responsabilidade individual. Para a demonstração desse argumento, Dworkin retoma o seu conhecido artifício representativo de um leilão inicial de todos os recursos disponíveis, do qual todos participariam com o mesmo número de fichas ${ }^{50}$. O leilão deve terminar numa situação na qual ninguém inveje o pacote de recursos, adquirido pelo outro (não importa quanto tempo dure o leilão, e nem quantas vezes deva ser refeito até que se chegue a esse resultado). Depois, segue-se um novo leilão, no qual os participantes constroem e escolhem apólices de seguro compreensivas, pagando o prêmio estabelecido pelo mercado para cada uma das coberturas escolhidas. Esse leilão não elimina as consequências da boa ou má sorte, mas torna as pessoas responsáveis pelo seu próprio gerenciamento de risco ${ }^{51}$.

A teoria da igualdade de recursos presume que nós tratamos as pessoas com igual consideração (ou seja, promove a igualdade) quando permitimos que cada um desenhe a sua própria vida (ou seja, promove a liberdade), ciente de que suas escolhas terão, dentre outras consequências, um impacto na sua própria riqueza. Satisfeitas essas condições, um governo terá respeitado e promovido simultaneamente a liberdade e a igualdade, sem sacrificar nenhum desses valores. Isto é, os princípios justificadores dos direitos à liberdade são os mesmos que fundamentam o direito à igualdade, ou seja, igual consideração e respeito e responsabilidade individual. $O$ ponto defendido por Dworkin aqui é: não há um conflito efetivo entre igualdade e liberdade porque esses conceitos estão fortemente integrados. São interdependentes. Não se pode determinar o que a liberdade requer sem também decidir qual distribuição de recursos e oportunidades demonstra igual consideração por todos. Assim, uma teoria da liberdade, que está desta forma envolvida numa moralidade política muito mais abrangente, não pode conflitar com a igualdade ${ }^{52}$.

50 Em A Virtude Soberana a metáfora do leilão aparece na construção do conceito da "igualdade de recursos", uma teoria geral da igualdade distributiva que afirma que se trata as pessoas como iguais quando se "distribui ou transfere de modo que nenhuma transferência adicional possa deixar mais iguais suas parcelas do total de recursos", DWORKIN, Ronald. A Virtude Soberana: A Teoria e a Prática da Igualdade, p. 5.

51 Vale notar que Dworkin sempre foi um crítico severo da estrutura econômica presente na maioria dos países ricos, entre eles, os Estados Unidos da América. E é esse gap entre a teoria e a política que faz com que os autores recorram a exercícios contrafáticos, como o estado de natureza de Hobbes, a posição original e o véu da ignorância de Rawls e o leilão inicial do próprio Dworkin, para a definição de justiça política. Curiosamente, o autor aponta que as teorias de justiça distributiva quase sempre demandam por uma reforma radical das comunidades capitalistas nas quais elas próprias são desenvolvidas e estudadas, o que faz com que soem artificiais e autoindulgentes. Ainda assim, devem demonstrar os passos mínimos que devemos tomar, aqui e agora, na direção certa.

${ }^{52} \mathrm{Em} O$ Direito da Liberdade, Dworkin já adiantava essa concepção de que a liberdade, de alguma forma, é interdependente da igualdade (do direito à igual consideração e respeito), nestes termos: "o Estado deve tratar todas as pessoas sujeitas a seu domínio como dotadas do mesmo status moral e político; deve tentar, de boa-fé, tratar a todas com a mesma consideração (equal concern); e deve respeitar todas e quaisquer liberdades individuais que 
Assim, conceitos morais básicos como os de justiça, liberdade e igualdade seriam não conflitantes, mas reciprocamente constitutivos. Esse ponto é central: a adequada compreensão do significado do holismo moral e da epistemologia integrada para o sistema filosófico dworkiniano é indispensável para entender a evolução do pensamento jurídico do autor ao longo da sua trajetória intelectual; nesse sentido, Justice for Hedgehogs deve ser vista, cremos, como uma obra que consolida avanços decisivos na teoria do direito como integridade. De fato, a exposição da sua teoria do direito em obras como A Matter of Principle e Law's Empire sugeria que a concepção de coerência que explicava o direito como integridade endereçava-se especialmente para a coerência entre textos legislativos e precedentes entre si e entre os princípios de moralidade política justificadores desse material normativo que pudessem ser deduzidos da história institucional daquele sistema jurídico específico. Fosse apenas isso, de fato a teoria do direito como integridade poderia ser entendida como associada a uma teoria moral relativista. Arthur Maria Ferreira Neto sintetiza bem essa percepção:

Assim, as expressões "real" ou "objetivamente não são capazes de modificar o sentido de juízos práticos, mas apenas adquirem sentido (como um paliativo de objetividade) na medida em que fazem parte de um empreendimento humano coletivo. Isso fica evidente quando DWORKIN afirma que a busca pelo ideal de integridade não representa um projeto que vise a fornecer elementos coerentes que possa ser aplicados de modo universal entre variadas comunidades políticas, mas é um critério que somente pode ser aplicado dentro de uma comunidade específica. Assim, o que é coerente em um contexto social poderia ser visto como incoerente em outro contexto social ${ }^{53}$.

Essa interpretação não dá a devida atenção ao papel que o princípio geral da igual consideração e respeito já então exercia na justificação e na correção das interpretações do material jurídico básico e dos princípios de moralidade política deduzíveis de um sistema jurídico específico. O resultado da interpretação sistemática das leis, precedentes e seus princípios justificadores deve ser contrastado com valores morais independentes que são inerentes à prática do direito, valores que tanto podem exigir a correção de uma resposta obtida na fase anterior quanto podem oferecer uma resposta que não fora fornecida de modo algum pelo material jurídico básico e pelos princípios morais expressos ou implícitos no sistema jurídico.

Como já vimos, o valor fundamental em torno do qual Dworkin constrói a sua filosofia moral e jurídica é o princípio da igual consideração e respeito, central à sua teoria do direito desde os textos compilados em Taking Rights Seriously. Em Justice for Hedgehogs, Dworkin refina um outro conceito moral, a dignidade humana - associado ao da igual consideração e respeito -, que pelo menos desde Is Democracy Possible Here?, de 2002, vinha ganhando maior precisão conceitual. O conceito de dignidade humana exposto na obra divide-se em: (i) o princípio do

53 FERREIRA NETO, Arthur Maria. A Metaética e a Fundamentação do Direito, p. 292-293. 
autorrespeito (principle of self-respect), pelo qual cada pessoa deve levar a sua vida a sério, ou seja, deve aproveitar, ao invés de desperdiçar, a sua oportunidade de viver: há, com efeito, uma importância objetiva em se viver bem, de modo que devemos tratar nossas vidas como dotadas dessa importância. De acordo com esse subprincípio, a vida humana tem uma importância intrínseca que deve ser respeitada por todas as pessoas e especialmente pelo Estado; e (ii) o princípio da autenticidade (principle of authenticity), segundo o qual cada um tem a responsabilidade de identificar aquilo que conta como sucesso em sua própria vida (já que você se leva a sério - pondera o autor -, viver bem expressa o seu próprio estilo de vida, a maneira com a qual você a encara) ${ }^{54}$. Por força desse subprincípio, as pessoas e o Estado devem respeitar as escolhas e as decisões que cada indivíduo adota no uso da responsabilidade que cada um de nós tem em viver bem a vida 55 .

Os princípios da igual consideração e respeito e da dignidade humana são princípios de moralidade geral a partir dos quais podem ser deduzidas especialmente as obrigações políticas que são típicas do direito. A regulação estatal das relações externas entre as pessoas através do direito só é legítima quando o Estado usa seus poderes respeitando a dignidade das pessoas e tratando-as com igual consideração e respeito. A rigor, o próprio princípio da igual consideração e respeito, onipresente em sua obra, jamais foi propriamente apresentado como dependente de um sistema jurídico qualquer, mas sim como inerente à natureza mesma da experiência jurídica. Se a nossa interpretação está correta, no sistema filosófico concluído em Justice for Hedgehogs, esses princípios morais transcendem os sistemas jurídicos particulares e operam como critérios últimos de legitimação político-moral de uma ordem jurídica e como fonte de direitos morais que podem ser reivindicados pelos indivíduos em processos judiciais. A natureza transcendente deste princípio encontra-se bem explicitada na seguinte passagem da obra em estudo:

Uma comunidade política não tem nenhum poder moral de criar e impor coercitivamente (enforce) obrigações contra seus membros a menos que os trate com igual consideração e respeito; isto é, a menos que as suas decisões políticas tratem os destinos de seus membros como igualmente importantes e respeitem as suas responsabilidades individuais por suas próprias vidas. Este princípio de legitimidade é a fonte mais abstrata de direitos políticos. O governo não tem nenhuma autoridade moral de usar a coerção contra qualquer pessoa, mesmo que seja para melhorar o bem-estar ou a bondade da comunidade como um todo, a menos que respeite essas duas exigências em relação a todas as pessoas. Os princípios da dignidade, portanto, estabelecem direitos políticos muito abstratos: eles prevalecem sobre políticas coletivas do governo. Nós moldamos esta hipótese: todos os direitos políticos são derivados deste direito fundamental. Definimos e defendemos direitos particulares perguntando-nos, em muito mais detalhe, o que a igual consideração e respeito exige $^{56}$.

\footnotetext{
${ }^{54}$ DWORKIN, Justice for Hedgehogs, p. 203-204.

${ }_{55}$ Ver especialmente o capítulo 09 de Justice for Hedgehogs.

${ }^{56}$ DWORKIN, Ronald. Justice for Hedgehogs, p. 330.
} 
Se a visão que estamos defendendo está correta, então a concepção de integridade da teoria dworkiniana do direito vai além da mera coerência intrassistemática de uma determinada ordem jurídica. A interpretação do direito exige também coerência moral com princípios de moralidade política que não são necessariamente incorporados a esta ordem jurídica institucional. Essa é uma consequência da concepção de que o direito é um galho da moralidade política, que, por sua vez, pertence à árvore do valor. É uma consequência da integração do sistema do direito com o sistema da moral, exposto no capítulo 19 da obra em estudo. Os princípios político-morais da dignidade e da igual consideração e respeito operam como condição de legitimidade do direito estatal e como fonte material de direitos jurídicos, isto é, de direitos morais que podem ser reivindicados institucionalmente pelos indivíduos, e essa proposição filosófico-moral vale para qualquer sistema jurídico ${ }^{57}$.

\section{A TESE DA RESPONSABILIDADE}

Sabemos agora que o valor é um domínio independente da racionalidade humana e que os múltiplos valores humanos devem ser compreendidos como pertencendo a uma unidade. Sabemos também que a coexistência entre estes múltiplos valores requer uma epistemologia integrada e que este método une esses valores e permite que se complementem de forma coerente. A questão que sempre retorna quando se estudam as ideias de Dworkin é: como é de fato possível obter sempre uma resposta certa para todos os casos difíceis do direito ou para todos os conflitos morais? Como integramos democracia representativa e proteção judicial de direitos, privacidade e liberdade de expressão, liberdade de expressão e proteção da segurança pública, liberdade econômica e proteção do meio ambiente? Estes valores concorrem com tanta frequência que, muitas vezes, não parece haver alternativa senão escolher um deles e sacrificar o outro.

Em artigo célebre, escrito quando Dworkin era ainda um jovem professor, embora já um agudo rival teórico, H.L.A. Hart profetizou que a tese da única resposta certa estava fadada a ser a questão mais polêmica da teoria do direito dworkiniana ${ }^{58}$. Hart tinha razão. Desde então, e ainda

57 Sobre o conceito de direitos políticos, ver, especialmente, Taking Rights Seriously. Para entender melhor este ponto, é preciso ter presente que, para Dworkin, direito e democracia estão reciprocamente implicados. Quer dizer, se a força estatal não pretende reivindicar autoridade moral para a sua ação, não se está diante de um sistema jurídico. De um ponto de vista moral, por exemplo, seria mais adequado negar que os comandos de um regime de força, como o nazista, fossem considerados "direito". A propósito do tema, cabe conferir suas reflexões respeito do chamado enigma do direito mau (evil Law puzzle), que aparecem no capítulo 19 de Justice for Hedgehogs.

58 H.L.A, HART. American Jurisprudence through English Eyes: The Nightmare and the Noble Dream, de 1977: "se eu posso arriscar uma profecia, eu acho que a principal crítica que (a filosofia jurídica de Dworkin) irá atrair será acerca da sua insistência em que, mesmo quando não existe nenhuma forma de demonstrar qual de duas soluções 
hoje, é esse o tema que mais desperta resistência teórica entre as tantas teses da teoria do direito do autor. Não por outra razão, Dworkin também dedicou muitos de seus textos para aprimorar e justificar a sua tese mais polêmica. Em Justice for Hedgehogs, a resposta de Dworkin aos críticos das teses da única resposta certa e ao argumento da unidade do valor se encontra na teoria da responsabilidade moral.

Segundo o autor, se não podemos esperar concordância dos nossos concidadãos quando debatemos essas questões morais, políticas e jurídicas extremamente controversas e que dividem a sociedade, podemos ao menos exigir deles responsabilidade na reflexão e na argumentação de suas posições. Precisamos, diz o autor, desenvolver uma teoria da responsabilidade que tenha força suficiente para que digamos às pessoas: "Discordo de você, mas reconheço a integridade do seu argumento. Reconheço a sua responsabilidade moral" ou "Concordo com você, mas você não foi responsável na formulação de seu argumento. Você atirou uma moeda para o alto ou acreditou naquilo que você ouviu num programa televisivo tendencioso. Não passa de um acidente que você tenha chegado à verdade" 59 .

Não há como demonstrar que um argumento moral é correto. Argumentos morais não podem ser demonstrados verdadeiros por correspondência a qualquer fato ou objeto do mundo empírico; não há como sustentá-los sem pressupor ou aceitar outros argumentos morais. O que se pode fazer é exigir de quem o formula responsabilidade na reflexão e na argumentação sobre questões morais. Insistindo no exemplo acima, eu posso estar certo, por hipótese, com relação à justiça das cotas raciais tendo formado a minha opinião num jogo de cara-ou-coroa e estar errado, quanto a este mesmo assunto, depois de uma demorada reflexão. Contudo, eu teria sido irresponsável no primeiro caso e responsável no segundo. E a distinção entre um e outro argumento passa a ser o tema dessa almejada teoria da responsabilidade.

A epistemologia moral de Dworkin é, portanto, uma espécie de teoria da responsabilidade moral, segundo a qual podemos conferir se nosso raciocínio moral é bom ou mau - o que, também, diga-se, é uma questão moral substantiva. Utiliza-se parte de uma teoria geral do valor para conferir a integridade do raciocínio no restante. Neste sentido, o autor concebe o raciocínio moral como uma atividade integralmente interpretativa. Lembremos: para Dworkin, uma

conflitantes, ambas igualmente bem justificadas pelo direito vigente, é a correta, ainda assim deve haver uma única resposta certa esperando para ser descoberta." Ver HART, H.L.A. Essays in Jurisprudence and Philosophy. Oxford: Clarendon Press, 2001, p. 139-140.

${ }^{59} \mathrm{~A}$ associação entre coerência e responsabilidade na formulação de argumentos já aparecia em Levando os Direitos a Sério. Basta lembrar da chamada "doutrina da responsabilidade política", mediante a qual Dworkin sustenta "que as autoridades políticas devem tomar somente as decisões políticas que possam justificar no âmbito de uma teoria política que também justifique as outras decisões que eles se propõem a tomar". DWORKIN, Ronald. Levando os Direitos a Sério, p. 137. 
interpretação em particular é exitosa (quer dizer, atinge a verdade a respeito do sentido de algum objeto) quando consegue situar o objeto em questão em relação aos propósitos da prática interpretativa identificados como pertinentes e o apresenta à sua melhor luz. E, como vimos antes, desde um ponto de vista analítico ao menos, a interpretação divide-se em três etapas. Primeiro, nós individualizamos essas práticas (por exemplo, definimos se estamos diante de interpretação jurídica ou literária); segundo, atribuímos um conjunto de propósitos ao gênero ou subgênero que identificamos como pertinentes; e, terceiro, tentamos identificar a melhor realização daquele conjunto de propósitos numa ocasião em particular ${ }^{60}$.

Agora vejamos como isso se dá, na visão do autor, com relação à implantação dos conceitos morais. Desde a infância, nós introjetamos conceitos morais (a partir do convívio com nossos pais, com o meio cultural etc.), especialmente, um conceito de fairness ${ }^{61}$; depois, vamos desenvolvendo outros, mais sofisticados, como a generosidade, a bondade, o dever de cumprir promessas, os direitos e os deveres. Na sequência, tomamos contato com conceitos políticos (direito, democracia, liberdade etc.). Esse conjunto de opiniões vai ficando mais detalhado nos desafios morais cotidianos da família, do comércio e da vida política. Segundo Dworkin, isso tudo nós interpretamos, ainda que irrefletidamente, tomando cada um destes conceitos à luz dos demais. A interpretação une esses valores, formando uma rede onde cada um destes valores, que aceitamos autenticamente, serve de apoio ao outro, em relação de reciprocidade ${ }^{62}$. "A verdade de cada juízo moral verdadeiro consiste na verdade de um número indefinido de outros juízos morais"63. O nosso pensamento seria dirigido, assim, à unidade.

Explicando melhor: nossos juízos morais são interpretações de conceitos morais básicos, e nós testamos essas interpretações colocando-as num quadro maior do valor para verificar tanto se elas se encaixam adequadamente como também para ver se elas estão apoiadas por aquilo que entendemos serem as melhores concepções de outros conceitos. A moral como um todo, e não apenas a moralidade política, é um empreendimento interpretativo. E a interpretação é, como se viu, uma questão de responsabilidade, não é uma questão de demonstração factual ou de correspondência com alguma realidade exterior ao argumento. Não existe um ponto arquimediano com base nos quais possamos testar nossas interpretações e assim nos sentirmos seguros sobre nossas convicções. Juízos morais não se sustentam a si mesmos, como os conceitos de fatos físicos. Tudo o que podemos fazer é sermos responsáveis no processo de interpretação de cada conceito e de cada valor e de como eles interagem e se complementam na vida de cada pessoa e

\footnotetext{
60 DWORKIN, Ronald. Justice for Hedgehogs, p. 131.

61 Neste contexto, fairness deve ser compreendido como justiça ou equanimidade.

62 DWORKIN, Ronald. Justice for Hedgehogs, p. 101.

63 DWORKIN, Ronald. Justice for Hedgehogs, p. 117.
} 
nas relações sociais e políticas. Temos que ter a responsabilidade de pensar bem antes de agir e de decidir.

Ser responsável, então, é construir uma rede integrada de argumentos racionais na qual cada conceito seja examinado isoladamente e em conjunto cuidadosamente, procurando compreender as finalidades fundamentais de cada valor e como elas podem reforçar os outros valores, de tal modo que não apenas não haja sacrifício, mas haja, inclusive, apoio recíproco e promoção. Haverá inevitavelmente divergências que muitas vezes parecerão irreconciliáveis, mesmo entre pessoas moralmente responsáveis, mas não podemos evitá-las, não podemos buscar refúgio nas verdades factuais. Temos que enfrentar as divergências no mundo dos argumentos, acreditando que podemos superá-las e encontrar a resposta certa. E se depois desse esforço responsável em busca da unidade do valor concluirmos que não existe uma resposta que unifique os valores concorrentes, e que inevitavelmente teremos que escolher um em detrimento de outro, então esta será a resposta certa. Porém, teremos chegado neste ponto responsavelmente, e não apenas porque ficamos paralisados por nossas incertezas morais. No parágrafo final do capítulo sobre interpretação em geral, Dworkin adverte o leitor:

\begin{abstract}
Não conseguimos evitar uma sensação de vacuidade e contingência nas nossas convicções interpretativas, porque sabemos que outras pessoas pensam aquilo que nós não podemos pensar e que não existe uma alavanca de um argumento que possamos acionar para as convencer. Ou para que eles nos convençam. Não há experiência que possa reconciliar as nossas certezas diferentes. Contudo, ficamos em uma posição de incerteza, não de niilismo. Se eu quiser mais - se quiser o sossego de um ceticismo interpretativo -, devo argumentar nesse sentido, mas os argumentos serão tão vagos, controversos e pouco convincentes para os outros quanto os argumentos positivos que agora não Ihe satisfazem. Assim - mais uma vez -, no fim tudo depende daquilo que você, real e responsavelmente, pensa. Não porque o seu pensamento torne certa uma coisa, mas porque, pensando da maneira certa, você pensa certo ${ }^{64}$.
\end{abstract}

Será que a tese da responsabilidade é suficiente para sustentar uma teoria da objetividade dos valores morais? Será ela suficiente para amparar a tese da resposta certa no âmbito da teoria do direito como integridade? Sabidamente um dos grandes desafios teóricos da ciência jurídica contemporânea encontra-se na elaboração de uma metodologia jurídica que seja capaz de oferecer o maior grau possível de objetividade aos juízos de justificação de decisões judiciais, especialmente aquelas que aplicam normas jurídicas que remetem a valores morais, como princípios e direitos fundamentais. Essa é a razão pela qual a teoria do direito tem hoje tanto interesse pela filosofia moral, inclusive pela metaética. Uma parte significativa dos debates teóricos no constitucionalismo contemporâneo referem-se a este problema. Essa é, também, a

${ }^{64}$ DWORKIN, Ronald. Justice for Hedgehogs, p. 163. 
razão do sucesso acadêmico e judicial de abordagens metodológicas que deflacionam o recurso a juízos morais na argumentação jurídica, como o princípio da proporcionalidade ${ }^{65}$.

É possível que a tese da responsabilidade frustre teóricos e práticos que esperavam de Dworkin uma metodologia com um roteiro mais objetivo do que a mera exortação ao rigor reflexivo e argumentativo. No entanto, a tese da responsabilidade, articulada no contexto de uma obra de filosofia prática geral, não expurga o recurso à metodologia da decisão judicial apresentada especialmente em Law's Empire; ao contrário, por um lado, quando aplicada a tese ao raciocínio jurídico, a metodologia do direito como integridade a pressupõe; por outro, a tese oferece uma base de sustentação filosófica que pode guiar e amparar o intérprete nos momentos mais desafiadores da tarefa de construção interpretativa de soluções jurídicas, que 0 autor simbolicamente delegou à figura mítica do juiz Hércules.

Todavia, essa é uma questão decisiva e precisa ser enfrentada por um artigo crítico, não em um ensaio basicamente expositivo. Nosso objetivo aqui era de apresentar da forma mais fiel e sistemática possível a sequência de concepções teóricas que constituem o sistema filosófico exposto em Justice for Hedgehogs. Como quase tudo o que Dworkin escreveu, trata-se de uma tese provocativa, que exige serenidade, paciência e acuidade na compreensão das suas ideias, antes de partirmos para um eventual contraponto. Podemos rejeitar, no todo ou em parte, as propostas de Dworkin; mas não há como deixar de reconhecer a sua responsabilidade moral em cada uma de suas formulações. Uma resposta conscienciosa, portanto, não exigiria menos.

\section{CONSIDERAÇÕES FINAIS}

Dworkin foi sempre um pensador ousado, desafiador e ambicioso. Ele enfrentou a teoria do direito amplamente dominante em seu meio intelectual não apenas atacando suas principais teses, no que podemos considerar a pars destruens do seu projeto teórico, como propôs, desenvolveu, defendeu e aperfeiçoou uma teoria do direito não-positivista particularmente inovadora, a hoje famosa teoria do direito como integridade, no que podemos chamar de pars construens do seu projeto teórico. Desde seus primeiros escritos, o autor insistiu na tese da conexão necessária entre direito e moral, um anátema para a filosofia analítica do direito desde 0 século XIX. A evolução do seu pensamento jurídico o levou a explorar a filosofia moral e a filosofia

65 Para uma crítica à articulação do princípio da proporcionalidade pelo Supremo Tribunal Federal, ver: MORAIS, Fausto Santos de. Ponderação e arbitrariedade: a inadequada recepção de Alexy pelo STF. Salvador: Juspodivm, 2016. 
política a fim de encontrar fundamentos filosóficos que pudessem sustentar a sua teoria do direito. Por muito tempo Dworkin propôs que qualquer teoria do direito está fundada em alguma forma de filosofia política, tese que encontrou apoio, inclusive, em críticos positivistas da sua teoria do direito, como Jeremy Waldron. Justice for Hedgehogs representa o estágio final de um avanço que já vinha sendo exposto pelo autor em obras anteriores: uma teoria do direito não apenas está fundada em uma filosofia política, mas é, necessariamente, parte da experiência moral humana.

$\mathrm{Na}$ obra que examinamos neste ensaio, Dworkin condensa o sistema filosófico que vinha desenvolvendo ao longo de sua trajetória intelectual e estrutura organicamente os argumentos que servem de fundamento filosófico para a sua teoria do direito. A obra é inegavelmente mais abrangente e explora questões filosóficas que transcendem amplamente as preocupações dos teóricos do direito. No ensaio, contudo, nos detivemos exclusivamente nos argumentos que dão suporte à teoria do direito como integridade. Como vimos, a estrutura da fundamentação filosófica da teoria não-positivista do direito do autor, tal como apresentada na sua forma final em Justice for Hedgehogs, está assentada basicamente em uma tese geral, segundo a qual o direito pertence ao domínio da moral; e em três teses especiais; que suportam a teoria geral: (i) a tese da independência do valor, a qual afirma que juízos morais não dependem de fatos morais ou de propriedades morais de objetos do mundo físico, e sim de uma argumentação moral substantiva; (ii) a tese da unidade do valor, segundo a qual os múltiplos valores morais podem ser unificados de forma coerente, a fim de formar uma rede interligada de valores que se reforçam reciprocamente; e (III) a tese da responsabilidade moral, pela qual a demonstração de que um argumento moral é objetivamente verdadeiro depende de uma interpretação responsável dos conceitos morais pertinentes, baseada no que ele denominou de epistemologia integrada. Tratase, parece evidente, de um projeto teórico altamente ambicioso. Enquanto a filosofia analítica do direito buscou incansavelmente desenvolver e defender a autonomia teórica do direito vis-à-vis a moral e a política, Dworkin procurou diluir o direito em um sistema filosófico abrangente, exatamente como haviam feito grandes filósofos antigos, como Platão, Tomás de Aquino, Kant e Hegel. Independentemente do êxito teórico do seu projeto, podemos reconhecer que Dworkin resgatou a ambição filosófica para a teoria do direito.

\section{REFERÊNCIAS DAS FONTES CITADAS}

BELIN, Isaiah. O Ouriço e a Raposa. In: Ensaios sobre a Humanidade. São Paulo: Companhia das Letras, 2002. 
The Hedgehog and the Fox: an essay on Tolstoi's view of history. Elephant Paperbacks, Chicago, 1993.

. Two Concepts of Liberty. In: BERLIN, Isaiah. Liberty. Oxford: Oxford University Press, 2009.

BLACKBURN, Simon. Essays in Quase-Realism. Oxford: Oxford University Press, 1993.

Spreading the Word. Oxford: Oxford University Press, 1984.

DWORKIN, Ronald. A Justiça de Toga. São Paulo: editora WMF Martins Fontes, 2010.

A Virtude Soberana: A Teoria e a Prática da Igualdade. São Paulo: Martins Fontes, 2005.

Justice for Hedgehogs. Cambridge, Massachusetts, London: The Belknap Press of Harvard University Press, 2011.

Law's Empire. Cambridge, USA: Belknapp, 1986.

Levando os Direitos a Sério. São Paulo: Martins Fontes, 2002.

O Direito da Liberdade: A Leitura Moral da Constituição Norte-Americana. São Paulo: Martins Fontes, 2006.

. O Império do Direito. 2. ed. São Paulo: Martins Fontes, 2003.

Objectivity and Truth: you'd better believe it, texto de 1996. Disponível em: < http://cas.uchicago.edu/workshops/wittgenstein/files/2007/11/dworkin-objectivity-and-truth.pdf>. Acesso em 15.03.2017.

. Taking Rights Seriously. Cambridge, USA: Belknapp, 1977.

Uma Questão de Princípio. 2. ed. São Paulo: Martins Fontes, 2005.

FERREIRA NETO, Arthur Maria. Metaética e a Fundamentação do Direito. Porto Alegre: Elegantia Juris, 2015.

FINNIS, John. Lei Natural e Direitos Naturais. São Leopoldo: Editora Unisinos, 2006.

FISCHER, Andrew. Metaethics: An Introduction. London: Routledge, 2014.

GADAMER, Hans-Georg. Verdade e Método I: Traços Fundamentais de Uma Hermenêutica Filosófica. 6. ed. Petrópolis: Vozes; Bragança Paulista: Editora Universitária São Francisco, 2004. HART, H.L.A. Essays in Jurisprudence and Philosophy. Oxford: Clarendon Press, 2001.

O Conceito de Direito. São Paulo: WMF Martins Fontes, 2009.

HUME, David. Treatise of Human Nature. Oxford: Oxford University Press, 2000.

JOYCE, Richard. Essays in Moral Skepticism. Oxford: Oxford University Press, 2016.

MACEDO JR., Ronaldo Porto. Apresentação. In: GUEST, Stephen. Ronald Dworkin. Rio de Janeiro: Elsevier, 2010. 
Do Xadrez à Cortesia: Dworkin e a Teoria do Direito Contemporânea. São Paulo:

Saraiva, 2013.

MACKIE, John. Ethics: Inventing Right and Wrong. New York: Penguin, 1977.

MELLO, Cláudio Ari Pinheiro de. Verdade Moral e Método Jurídico na Teoria Constitucional de Ronald Dworkin. In: Alfredo Carlos Storck; Wladimir Barreto Lisboa. (Org.). Normatividade \& argumentação: ensaios de filosofia política e do direito. 1. ed.Porto Alegre: Linus Editores, 2013, p. 285-366.

MILLER, Alexander. An Introduction to Contemporary Metaethics. Cambridge, UK: Polity Press, 2003.

MORAIS, Fausto Santos de. Ponderação e arbitrariedade: a inadequada recepção de Alexy pelo STF. Salvador: Juspodivm, 2016.

MOTTA, Francisco José Borges. Ronald Dworkin e a Decisão Jurídica. Salvador: Juspodivm, 2017.

ROOJEN, Mark van. Metaethics: A Contemporary Introduction. London: Routledge, 2015.

SHAFFER-LANDAU, Russ. Truth and Metaethics: The Possibility of Metaethics, Boston University Law Review, vol. 90, n. 2 (abril 2010), p. 479-496.

(editor). Oxford Studies in Metaethics. Oxford: OUP, 2016.

SCHROEDER, Mark. Non-cognitivsm in Ethics. London: Routledge, 2010.

SMITH, Michael. Dworkin on External Skepcism, Boston University Law Review, vol. 90, n. 2 (abril 2010), p. 509-520.

STRECK, Lenio Luiz. Verdade e Consenso: Constituição, Hermenêutica e Teorias Discursivas. $4^{a}$ ed. São Paulo: Saraiva, 2011.

TIMMONS, Mark. Moral Theory: An Introduction. Maryland: Rowman and Littlefield Publishers, 2013.

Recebido em: mar/2017

Aprovado em: abr/2017 